Review article : coeliac disease in later life must not be missed

Collin, $\mathrm{P}$.

2018-03

Collin , P , Vilppula , A , Luostarinen , L , Holmes , G K T \& Kaukinen , K 2018 , ' Review article : coeliac disease in later life must not be missed ', Alimentary Pharmacology \& Therapeutics, vol. 47 , no. 5 , pp. 563-572 . https://doi.org/10.1111/apt.14490

http://hdl.handle.net/10138/232989

https://doi.org/10.1111/apt.14490

publishedVersion

Downloaded from Helda, University of Helsinki institutional repository.

This is an electronic reprint of the original article.

This reprint may differ from the original in pagination and typographic detail.

Please cite the original version. 


\title{
Review article: coeliac disease in later life must not be missed
}

\author{
P. Collin ${ }^{1,2}$ \\ A. Vilppula ${ }^{3}$ \\ L. Luostarinen ${ }^{4}$ \\ G. K. T. Holmes ${ }^{5}$ \\ K. Kaukinen ${ }^{6}$
}

${ }^{1}$ Department of Gastroenterology and Alimentary Tract Surgery, Tampere University Hospital, Tampere, Finland

${ }^{2}$ University of Tampere, Tampere, Finland

${ }^{3}$ Department of Clinical Neurophysiology, Neuroscience, HUS Medical Imaging Centre, University of Helsinki, Helsinki University Hospital, Helsinki, Finland

${ }^{4}$ Päijät-Häme Central Hospital, Lahti, Finland

${ }^{5}$ Department of Gastroenterology, the Royal Derby Hospital, Derby, UK

${ }^{6}$ Department of Medicine, Faculty of Medicine and Life-Sciences, Tampere University Hospital, University of Tampere,

Tampere, Finland

\section{Correspondence}

Prof. P Collin, Department of

Gastroenterology and Alimentary Tract Surgery, Tampere University Hospital,

Tampere, Finland.

Email: Pekka.Collin@uta.fi

Funding information

Academy of Finland; The Expert

Responsibility area of Tampere University

Hospital; The Sigfrid Juselius Foundation

\section{Summary}

Background: The presenting symptoms of coeliac disease are often subtle and the diagnosis is frequently delayed or overlooked. Therefore, especially elderly patients may be denied the benefits conferred by gluten free diet which can be dramatically life-changing.

Aim: To review the occurrence, clinical features, diagnosis and management in coeliac patients detected later in life.

Methods: To review manuscripts concerned with coeliac disease in the elderly and to derive subgroups of elderly people from publications on the disorder.

Results: Approximately a quarter of all diagnoses are now made at the age of 60 years or more and a fifth at 65 years or over. About $4 \%$ are diagnosed at 80 years or above. Around $60 \%$ remain undetected, since their symptoms are often subtle: tiredness, indigestion, reduced appetite. Good compliance with gluten free diet, resolution of symptoms and improvement in laboratory indices can be achieved in over $90 \%$ of patients.

Conclusions: Coeliac disease not uncommonly presents for the first time in older patients and is an important diagnosis to make. 


\section{1 | INTRODUCTION}

In past decades, coeliac disease was thought to mainly affect children and young adults. Today we have learnt that the disorder may be detected at any age, and is regarded as one of the commonest chronic disorders encountered worldwide with a serological prevalence of about $1 \%-2 \%{ }^{1,2}$ The advent of an endoscopic technique to obtain duodenal biopsies quickly and the development of reliable serological screening tests have been responsible for this remarkable turnaround.

In a proportion of older people the symptoms go back to childhood but the diagnosis of coeliac disease is not made because they either do not present to health care workers or the diagnosis is missed only to be arrived at often many years later. ${ }^{3}$ Compared to younger patients, the clinical picture may thus be different when the disease is diagnosed at advanced age. The diagnostic delay has probably been longer, and in any case, these individuals will have been consuming gluten for many decades. This may expose them to longterm consequences of malabsorption and to complications of coeliac disease. ${ }^{4}$ Some might argue why the diagnosis of coeliac disease should be pursued in the elderly, especially when symptoms are only mild and adopting a gluten free diet demands considerable changes in life style. The evidence points to the value of making the diagnosis in this population. Mild symptoms do not necessarily equate to a satisfactory quality of life in elderly people with coeliac disease without gluten free diet. $^{3}$ The case for pursuing the diagnosis in the elderly is compelling but patients of course, will make the final decision about how they wish to proceed. In any event, older people are increasingly unwilling to put up with ill health that might indicate coeliac disease and are rightly demanding investigation. Old age itself should never be blamed for clinical features such as tiredness, indigestion, reduced appetite or anaemia which may be due to coeliac disease. ${ }^{3,5}$

\section{REVIEW CRITERIA}

We searched PubMed, Medline and Cochrane library for articles published in English until May 2017. We used the terms celiac disease, coeliac disease, age, ageing, elderly, and dermatitis herpetiformis. We utilised such articles where it was possible to distinguish clinical features, diagnosis or management of coeliac disease later in life.

\section{PREVALENCE AND INCIDENCE}

The overall prevalence of coeliac disease in the elderly is expected to rise because life expectancy generally is getting longer, and the mortality rate is not much different from the population in general. ${ }^{6,7}$ Older people are increasingly unwilling to put up with ill health that might indicate coeliac disease and are rightly demanding investigation.
The published prevalence figures of coeliac disease vary widely, depending on the target population and the study design. Coeliac disease antibody testing, especially with IgA class endomysial antibodies and tissue transglutaminase antibodies, offers a powerful tool for screening, and most prevalence studies are therefore based on this approach ${ }^{8-10}$.

Epidemiological studies of coeliac disease in elderly people are sparse. In Finland, the overall prevalence of coeliac disease was $1.99 \%$, and $1.2 \%$ in the patients over 75 years of age. ${ }^{1}$ Casella et al found that in their cohort comprising 1225 coeliac disease patients, $4.8 \%$ were over 65 years of age at the time of examination. ${ }^{11}$ In a further series only $4.4 \%$ were over the age of 65 years at diagnosis. ${ }^{12}$ Tortora et al $^{13}$ reported an even lower percentage; in their series only $2.5 \%$ were detected in individuals over 65 years of age. This series was collected in a tertiary referral centre and almost certainly referral bias was responsible for this low result. More realistic figures come from the coeliac disease clinic in Derby, UK, which is not a referral centre. Here, $28 \%$ and $21 \%$ were diagnosed by small intestinal biopsy at the ages of 60 years or more or 65 years and over, respectively. ${ }^{14}$ About $4 \%$ were diagnosed at or over the age of 80 years. Among the Asian population there is a dearth of diagnoses in later life. Only $5 \%$ of Asians were diagnosed in the Derby clinic at or over the age of 60 years which is far less than for whites. ${ }^{14}$ In a series from New Delhi, only $9 \%$ were diagnosed at the age of 50 years or more. ${ }^{15}$ Whether coeliac disease is uncommon in elderly Asians or these individuals are not presenting for diagnosis remains to be determined.

It is possible to derive prevalence data from many publications focusing on the epidemiology of coeliac disease. Table 1 summarises such screening studies, where the prevalence figures in the whole study population and in subgroups of older people can be estimated. The prevalence figures seem in general to be lower in older series than in the general population. As the Table shows, the Finnish study seems to make an exception, reporting a higher prevalence of coeliac disease in elderly patients. ${ }^{16}$ These differences may be due to patient selection; the Finnish study was population-based, and also included patients already diagnosed on clinical grounds prior to screening.

The prevalence figures in screening studies must be differentiated from those obtained in clinical practice. Figures for the occurrence of diagnosed coeliac disease are much lower than what have been reported in screening studies. Apart from study population and design, figures obtained depend on the diagnostic accuracy and the use of serologic screening in everyday clinics. Vilppula et $\mathrm{al}^{17}$ reported that the frequency of clinically detected coeliac disease in patients over 50 years of age was $0.89 \%$, while the overall population prevalence in same area was $0.5 \%-0.7 \%$ over approximately the same period. ${ }^{18}$.

As stated earlier, endomysial antibodies and tissue transglutaminase antibodies afford a high specificity for coeliac disease. Moreover, seropositive individuals with normal villous architecture often develop coeliac disease later in life. ${ }^{19}$ Therefore, the combined biopsy-proven and seroprevalence is of interest. The Finnish series 
TABLE 1 The prevalence of coeliac disease; the figures in different age groups have been derived from the Results of the original publication

\begin{tabular}{|c|c|c|c|c|c|c|c|}
\hline Study, year & Country & Population & $\begin{array}{l}\text { Screening } \\
\text { method }\end{array}$ & $\begin{array}{l}\mathrm{n} \text { total } \\
\mathrm{n} \text { subpopulation }\end{array}$ & $\begin{array}{l}\text { Population age } \\
\text { subpopulation } \\
\text { age (y) }\end{array}$ & $\begin{array}{l}\text { Biopsy-proven } \\
\text { prevalence (\%) }\end{array}$ & $\begin{array}{l}\text { Sero-prevalence } \\
\text { (\%) }\end{array}$ \\
\hline \multirow[t]{2}{*}{ Kolho et al, $1998^{81}$} & \multirow[t]{2}{*}{ Finland } & \multirow[t]{2}{*}{ Voluntary personnel } & \multirow[t]{2}{*}{ EMA } & \multirow[t]{2}{*}{1070} & $18-65$ & 0.77 & 1.03 \\
\hline & & & & & $58-65$ & 0.09 & 0.18 \\
\hline \multirow[t]{2}{*}{ Ivarsson et al, $1999^{82}$} & \multirow[t]{2}{*}{ Sweden } & \multirow[t]{2}{*}{ General population } & \multirow[t]{2}{*}{ AGA, EMA } & \multirow[t]{2}{*}{1894} & $25-74$ & 0.53 & \multirow[t]{2}{*}{0.32} \\
\hline & & & & & $57-68$ & 0.37 & \\
\hline Volta et al, $2001^{83}$ & Italy & General population & EMA & 632 & $56-65$ & 0.32 & 0.57 \\
\hline \multirow[t]{2}{*}{ West et al, $2003^{2}$} & \multirow[t]{2}{*}{ UK } & \multirow[t]{2}{*}{ Health survey } & \multirow[t]{2}{*}{ EMA } & 7527 & $45-76$ & \multirow[t]{2}{*}{-} & 1.2 \\
\hline & & & & 4696 & $55-76$ & & 1.0 \\
\hline Catassi et al, $2007^{76}$ & USA & $\begin{array}{l}\text { Primary care at-risk } \\
\text { patients }\end{array}$ & TTGA,EMA & 976 & $\geq 18$ & - & 3.07 \\
\hline \multirow{2}{*}{ Lohi et al, $2007^{1}$} & \multirow{2}{*}{ Finland } & \multirow{2}{*}{$\begin{array}{l}\text { Heath survey, population } \\
\text { based }\end{array}$} & \multirow{2}{*}{ TTGA, EMA } & 812 & $65-74$ & \multirow{2}{*}{0.52} & 1.21 \\
\hline & & & & 747 & $\geq 75$ & & \\
\hline Vilppula et al, $2009^{16}$ & Finland & General population & TTGA, EMA & 2815 & $\geq 55$ & 2.34 & 2.70 \\
\hline Godfrey et al, $2010^{37}$ & USA & $\begin{array}{l}\text { Monoclonal gammopathy } \\
\text { study }\end{array}$ & TTGA, EMA & 16847 & $\geq 50$ & 0.2 & 0.8 \\
\hline \multirow[t]{2}{*}{ Katz et al, $2011^{84}$} & \multirow[t]{2}{*}{ USA } & \multirow{2}{*}{$\begin{array}{l}\text { Volunteer health care } \\
\text { participants }\end{array}$} & \multirow[t]{2}{*}{ TTGA, EMA } & 3850 & $\geq 18$ & - & 0.8 \\
\hline & & & & 2727 & $\geq 50$ & & 0.7 \\
\hline Almeida et al, $2013^{85}$ & Brazil & Unselected out-patients & TTGA, EMA & 946 & $\geq 60$ & 0.1 & \\
\hline
\end{tabular}

EMA, endomysial antibodies; AGA, gliadin antibodies; TTGA, tissue transglutaminase antibodies.

show that this was as high as $2.7 \%$ in individuals over 50 years of age (Table 1). ${ }^{16}$.

Like the prevalence data (Table 1), some incidence data in the literature can be obtained separately for elderly people. The overall annual incidence figures vary quite markedly (Table 2). This variability can be attributed to different diagnostic strategies and efficacy, and due to the overall diagnostic delay. In adults of all ages, the annual incidence figures have been inconsistent, but are in general not lower in older than in younger coeliac patients, as shown in Figure 1.

Coeliac disease is more common in females than males with an overall female to male ration of 2:1 in white populations. ${ }^{2,14,20}$ However, there was a paucity of diagnoses in young men $<20$ years of age giving a ratio of 4:1. This difference in gender diminished in later years. For those aged 60 years or over at diagnosis, the female male ratio was found to be $1.4: 1 .{ }^{14}$ What could help to explain these gender differences? Women are more likely to develop autoimmune disorders than men $^{21}$ and women use health-care facilities more than men so are more likely to be diagnosed with coeliac disease. Women are more symptomatic than $m^{22}$ and this may lead to earlier diagnosis and men may delay presenting to healthcare professionals. ${ }^{23}$ An interplay between sex hormones and the gastrointestinal microbiota may prevent men from developing coeliac disease. In rodents, it has been shown that this interplay increases the prevalence of autoimmunity in females. ${ }^{24}$ Increasing age might reduce this interplay as sex hormone levels decrease.

To conclude, coeliac disease, including undetected, is common in the elderly, the disorder may manifest at any age, seropositive individuals may later develop coeliac disease regardless of their age, and seropositivity may appear also later in life. ${ }^{16}$

\section{4 | CLINICAL MANIFESTATIONS}

\subsection{Symptoms and malabsorption}

Classic symptoms of coeliac disease are weight loss, diarrhoea, and fatty stools indicative of malabsorption. When these are present making the diagnosis of coeliac disease is relatively straight forward although it can still be overlooked. However, most patients now present with non-classical features such as fatigue; dyspepsia; vague abdominal pain suggestive of irritable bowel syndrome; ${ }^{25}$ constipation; and characteristics such as poor growth, anaemia, mouth ulcers, osteoporosis and neuropathy. This clinical diversity often delays or obscures the diagnosis of coeliac disease and particularly so in the elderly when it is easy to dismiss such symptoms as due to "old age" and of no real consequence. This was illustrated by a series reported by Hankey and Holmes ${ }^{3}$ who found a delay of 28 years in those diagnosed at the age of 60 years or over; the maximum delay was 
TABLE 2 The annual coeliac disease incidence per 100000 in different age groups; derived from the original publications

\begin{tabular}{|c|c|c|c|c|}
\hline Study, year & Country & Population & $\begin{array}{l}\text { Population age } \\
\text { Subpopulation age, (y) }\end{array}$ & $\begin{array}{l}\text { Incidence } \\
\text { All or female/male (\%) }\end{array}$ \\
\hline Murray et al, $2003^{86}$ & USA & Retrospective survey of cases, 1950-2001 & $\begin{array}{l}\text { Children and adults } \\
\geq 65\end{array}$ & 2.1 \\
\hline \multirow[t]{2}{*}{ Fowell et al, $2006^{87}$} & \multirow[t]{2}{*}{ UK } & \multirow[t]{2}{*}{ Prospective survey, 1993-2002 } & \multirow{2}{*}{$\begin{array}{l}\text { Adults } \\
60-74\end{array}$} & 8.7 \\
\hline & & & & 16.8 \\
\hline \multirow{2}{*}{ Virta et al, $2009^{18}$} & \multirow{2}{*}{ Finland } & \multirow{2}{*}{$\begin{array}{l}\text { Database of the National Social Insurance } \\
\text { Institution, 2004-2006 }\end{array}$} & $65-74$ & $53 / 47$ \\
\hline & & & $\geq 75$ & $24 / 22$ \\
\hline Vilppula et al, $2009^{16}$ & Finland & General population, 2002-2005 & $\geq 55$ & 75 \\
\hline Godfrey et al, $2010^{16}$ & USA & Stored sera, 2001-2011 & $\geq 50$ & 11.8 \\
\hline \multirow{3}{*}{ Angeli et al, $2012^{88}$} & \multirow{3}{*}{ Italy } & \multirow{3}{*}{$\begin{array}{l}\text { Prospective survey, 2001-2011 in a local } \\
\text { health unit }\end{array}$} & $65-69$ & $40 / 14$ \\
\hline & & & $70-74$ & $27 / 17$ \\
\hline & & & $75-79$ & $14 / 20$ \\
\hline \multirow[t]{3}{*}{ Ludvigsson et al, $2013^{89}$} & \multirow[t]{3}{*}{ USA } & \multirow[t]{3}{*}{ Prospective survey, 2000-2010 } & $0-85$ & 17.4 \\
\hline & & & $45-64$ & 19.0 \\
\hline & & & $65-85$ & 21.7 \\
\hline
\end{tabular}

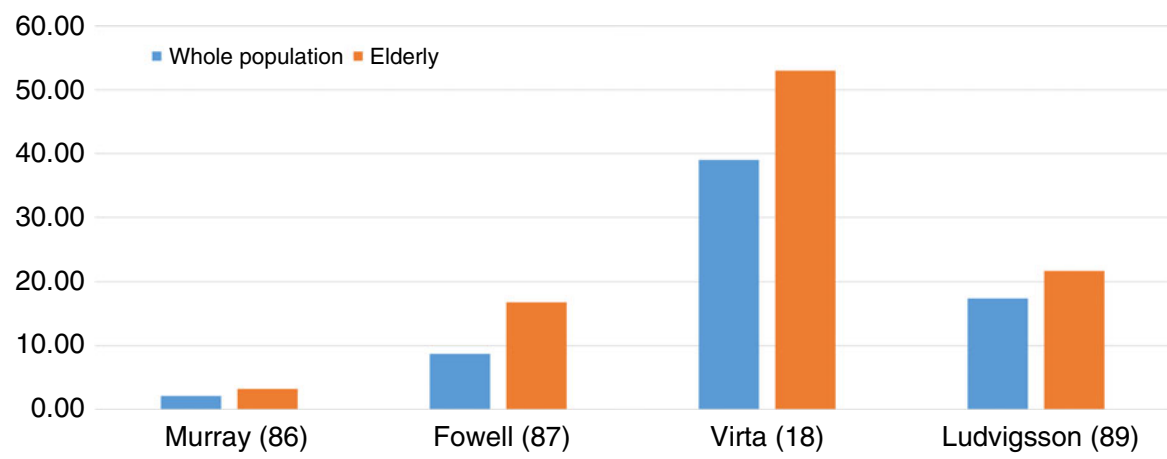

FIGURE 1 The annual incidence of coeliac disease per 100000 in the whole population and in the elderly (65 years or older in different studies). The respective references are shown in parentheses. Population: Murray and Ludvigsson all ages, Fowell 15 years and Virta 16 years or older an astonishing 50 years. It has to be conceded that this was in an era when awareness of coeliac disease was not as prominent as it is now. In a more recent cohort of elderly patients, ${ }^{26}$ the duration of symptoms was $6.14 \pm 12.6$ years, similar to that in young adults at $5.8 \pm 12$ years but unacceptably long delays still occur. Even in those presenting with classical manifestations, a diagnostic delay of 17 years can occur. ${ }^{12}$

In the study of Vivas et al, ${ }^{27}$ typical symptoms were present in $62.5 \%$ children vs $31 \%$ in adults $(P=0.01)$. The average time to diagnosis after the appearance of symptoms was 7.6 months for children and 90 months for adults $(P<0.001)$.

Tortora et $\mathrm{al}^{13}$ found no differences in the malabsorption values between young and elderly people. However, elderly coeliac patients were more likely than younger ones to be diagnosed due to malabsorption symptoms, whereas nonclassic symptoms were less common in the elderly. This suggests that elderly coeliac patients with subtle or atypical symptoms may go undetected by the health care staff.

Table 3 summarises some reports on symptoms or malabsorption in elderly people with coeliac disease. It is noteworthy that many patients had not suffered from any obvious symptoms.

\section{2 | Dermatitis herpetiformis}

Dermatitis herpetiformis is the classic cutaneous manifestation of extraintestinal coeliac disease. This is a blistering itching skin disease typically affecting elbows, knees, buttocks and scalp. Granular IgA deposits of the uninvolved skin are diagnostic. The disease affects up to $12 \%$ of adult coeliac patients. ${ }^{28}$ In contrast to coeliac disease, the incidence of dermatitis herpetiformis is decreasing. ${ }^{20,29}$ It was suggested that an early diagnosis and treatment of coeliac disease might lead to less dermatitis herpetiformis. ${ }^{28}$ The mean age at 
TABLE 3 Symptoms and signs of malabsorption in older patients with coeliac disease. Derived from the original publications

\begin{tabular}{|c|c|c|c|c|}
\hline Reference & n & Age, y & Symptoms & Malabsorption \\
\hline \multirow[t]{2}{*}{ Hankey and- Holmes, $\mathrm{UK}^{3}$} & \multirow[t]{2}{*}{42} & \multirow[t]{2}{*}{$>60$} & $45 \%$ classic symptoms & $80 \%$ anaemia (male) \\
\hline & & & $14 \%$ subtle symptoms & $75 \%$ anaemia (female) \\
\hline \multirow[t]{4}{*}{ Freeman et al, Canada 90} & \multirow[t]{4}{*}{30} & \multirow[t]{4}{*}{$>60$} & \multirow[t]{4}{*}{$77 \%$ weight loss } & $61 \%$ anaemia \\
\hline & & & & $40 \%$ iron deficiency \\
\hline & & & & $37 \%$ low vitamin B12 \\
\hline & & & & $30 \%$ low serum folate \\
\hline \multirow[t]{2}{*}{ Gasbarrini et al, Italy ${ }^{12}$} & \multirow[t]{2}{*}{60} & \multirow[t]{2}{*}{$>65$} & $77 \%$ classic symptoms & \multirow[t]{2}{*}{$58 \%$ anaemia } \\
\hline & & & $3 \%$ no symptoms & \\
\hline West et al, $\mathrm{UK}^{2}$ & 87 & $45-76$ & Not described & Blood haemoglobin was lower than in control group \\
\hline \multirow[t]{3}{*}{ Vilppula et al, Finland ${ }^{17}$} & \multirow[t]{3}{*}{60} & \multirow[t]{3}{*}{$>55$} & $31 \%$ classic symptoms & \multirow[t]{3}{*}{$50 \%$ anaemia or malabsorption } \\
\hline & & & $36 \%$ subtle symptoms & \\
\hline & & & $33 \%$ no symptoms & \\
\hline
\end{tabular}

Subtle symptoms, abdominal distention, occasional loose stools or diarrhoea, bloating.

Classic symptoms, chronic diarrhoea, malabsorption (iron, vitamin B12, folic acid), abnormal loss of weight.

diagnosis of dermatitis herpetiformis in our series was 39 years, which was not much different from that in coeliac disease (44 years). ${ }^{30}$ However, dermatitis herpetiformis is fairly uncommon in children; in our series only $4 \%$ of 476 patients were less than 17 years of age. ${ }^{28}$

B-cell lymphoma in dermatitis herpetiformis may develop more likely than in those with coeliac disease, who develop typically enteropathy-associated T-cell lymphoma. In our series, 11 of 1104 patients with dermatitis herpetiformis had non-Hodgkin lymphoma; eight B-cell lymphoma, two enteropathy-associated T-cell lymphoma, and one were unclassified. Six of the 11 were over 50 years of age (median 50 , range $32-79$ years). ${ }^{31}$

In general, the clinical course of dermatitis herpetiformis does not differ between young and elderly patients. A decreased mortality rate in dermatitis herpetiformis is an intriguing feature. Hervonen et $\mathrm{al}^{32}$ found the relative risk in mortality to be $0.7 ; 95 \%$ confidence intervals $(\mathrm{Cl})$ 0.55-0.87. A similar trend has been shown in smaller series, though not statistically significantly. ${ }^{7,33}$ The risk of lymphoma in the elderly should be borne in mind, including the B-cell type, although it may appear in younger people. ${ }^{31}$

\section{3 $\quad$ Bone mineral density and fractures}

Adult coeliac patients have more osteoporosis or osteopenia and altogether lower bone mineral density than the reference population $^{34,35}$ Osteoporosis, as would be expected, is much more prevalent in elderly coeliacs. In one series of patients 65 years or older at the diagnosis of coeliac disease by biopsy, $67 \%$ of males had osteoporosis compared with $14 \%$ in younger participants, while the corresponding figures for females were $70 \%$ and $9 \% .{ }^{11}$ Importantly, it has been found that reduced bone mineral density can affect those who have no symptoms of coeliac disease and are discovered by screening, ${ }^{5,34}$ or are children who have returned to a normal diet but have remained symptom free in adult life. ${ }^{35}$ Meta-analysis showed that there is a moderate reduction in bone mineral density in untreated coeliac disease with weighted T-scores at the lumbar spine and hip of -1.7 and -1.4 (osteopenia defined as T-score 1 to -2.4 an osteoporosis $\leq-2.5$ standard deviations). ${ }^{36} \mathrm{As}$ expected, the same seems to be true in the elderly, in whom osteopenia and osteoporosis are common. ${ }^{11,37,38}$

The fracture risk was higher in coeliac disease patients $(8.7 \%)$ than in a control population (6.1\%) according to a meta-analysis of Olmos et $\mathrm{al}^{39}$ In another study, a modest increase in risk of fracture was evident (risk ratio 1.38; $95 \% \mathrm{Cl} 1.14-1.68$ ). ${ }^{36}$ West et $\mathrm{al}^{38}$ in their population based study reported small increase in fractures in patients with coeliac disease (hazard ratio 1.30; 95\% Cl 1.16-1.46) but considered that undue concern was unwarranted. In some other small series, the fracture risk was also elevated. ${ }^{5}$

Osteoporosis can be reliable assessed by measurement of bone mineral density using non-invasive dual-energy $\mathrm{X}$-ray absorptiometry (DEXA) but the issue in practice is identifying which coeliac patients are at most risks of reduced bone mineral density so that investigations can be rationalised. High risk factors include age over 70 years, previous osteoporotic fracture, weight loss greater than $10 \%$, and low body weight. ${ }^{40} \mathrm{~A}$ case can therefore be made for limiting DEXA screening for osteoporosis to new patients with these features, to those with symptoms despite treatment with a gluten free diet for 1 year and to those who do not adhere strictly to the diet. The fracture risk assessment tool (FRAX) has been devised to limit the need for DEXA scans. ${ }^{41}$ The score is based in 10 variables. It appears to have a high negative predictive value of $94 \%$ but further evaluation of this test is required.

Osteoporosis is just one of many factors predisposing to fracture and the risk doubles with each standard deviation decrease in bone mineral density. ${ }^{42}$ Advice to the elderly about wearing good shoes and slippers and avoiding hazards that might lead to falls is particularly important to avoid fracture. Apart from dietary advice, this is especially important for coeliac disease patients. 
Among patients with osteoporosis, the prevalence of coeliac disease has been up to $3.4 \%{ }^{43}$ only slightly higher than the contemporary knowledge of the frequency of coeliac disease in the general population. Nevertheless, the possibility of coeliac disease should be considered in all subjects with osteoporosis or osteopenia, regardless of their age, since gluten free diet increases bone mineral density even in asymptomatic coeliac disease patients. ${ }^{34,35}$

Elevated alkaline phosphatase is a marker of osteomalacia in coeliac disease as in the general population. Normalisation of results with gluten free diet, vitamin $D$ and calcium will remove the need for further investigation including bone biopsy. ${ }^{4}$

\subsection{Autoimmune diseases and morbidity}

Screening studies have demonstrated an increased prevalence of autoimmune disorders including type 1 diabetes mellitus, thyroid disease and liver disorders. Of these diabetes is the best researched and in about $90 \%$ of patients diabetes precedes the diagnosis of coeliac disease. Apart from diabetes, hypothyroidism and hyperthyroidism, autoimmune liver disease and primary biliary cirrhosis deserve special mention. Isolated hypertransaminasemia is the most common hepatic injury and if this reverses on gluten free diet no further investigation is required. Primary Sjögren's syndrome must be remembered also in elderly coeliac disease patients. ${ }^{44}$ These associations have recently been reviewed in detail. $^{4}$

In elderly people, the concomitant occurrence of autoimmune conditions in coeliac disease does not differ from that in adults in general. ${ }^{13,45}$ In particular, hypothyroidism is often associated with coeliac disease in the elderly, ${ }^{17,37}$ although highest risk estimates for thyroid disease have been obtained in coeliac children. ${ }^{46}$ It is uncertain whether gluten free diet can alleviate or prevent the development of autoimmune disease, especially in adults. ${ }^{47,48}$

\subsection{Heart disease and neurological disturbances}

Apart from the burden of associated autoimmune diseases in coeliac patients, an increased risk of ischaemic heart disease has been reported. ${ }^{49}$ The overall risk of ischaemic heart disease in coeliac disease is still debatable, which may be due to differences in smoking patterns or socioeconomic factors. ${ }^{4}$ Recent studies have found no association between gluten intake and the risk of subsequent overall coronary heart disease. ${ }^{50,51}$ Nevertheless, gluten free diet may result in reduced consumption of beneficial whole grains, which may affect cardiovascular risk, and coeliac patients should be informed about the potential risks of ischaemic heart disease. ${ }^{51}$

Various neurological problems have been encountered in coeliac disease. Many of these associations are still debatable. Patients with these disturbances should be actively screened serologically for coeliac disease. Neuropathy, memory disturbances, ataxia of non-alcoholic origin and brain atrophy are conditions where coeliac disease may be associated..$^{52,53}$ The mean onset of gluten neuropathy and gluten ataxia occurs at the mean age of 55 years. ${ }^{53,54}$ It seems that elderly patients with coeliac disease are overall not at increased risk for dementia compared to population in general. ${ }^{55}$ Unfortunately, neurological conditions are often irreversible in spite of the introduction of a gluten-free diet. ${ }^{56,57}$

\subsection{Malignancy and mortality}

According to a recent meta-analysis coeliac disease patients, including screen-detected cases, were at an increased risk of non-Hodgkin lymphoma and of all-cause mortality, but not of malignancy in general. ${ }^{58}$ In clinically milder forms, the risk may be lower. ${ }^{6,59}$ The increase was due especially to enteropathy-associated T-cell lymphoma, and with poor dietary compliance. ${ }^{7,60}$ Lymphoma in young coeliac patients is uncommon, ${ }^{11}$ so the development of malignancy is mainly a concern in the elderly. In the review by Ludvigsson, the overall survival of coeliac patients with lymphoproliferative malignancy was the same as that of controls. ${ }^{61}$

In 2009 Freeman $^{62}$ stated in his review that when coeliac disease is diagnosed initially in elderly individuals or late in the clinical course, the risk of developing lymphoma and other malignancies was increased. In contrast, Godfrey et $\mathrm{al}^{37}$ observed that in coeliac patients over 50 years of age there was no significantly greater risk of cancer or mortality in the undiagnosed coeliac patients than in the controls.

In contrast to coeliac disease, the risk of B-cell lymphoma was increased in dermatitis herpetiformis patients. Similar to coeliac disease patients, the risk was associated with poor compliance to gluten-free diet, but as stated earlier, surprisingly the mortality rate was decreased in dermatitis herpetiformis. ${ }^{31,63}$

Refractory coeliac disease is a rare premalignant condition mainly affecting elderly coeliac disease patients. ${ }^{64,65}$ The symptoms and mucosal lesions do not alleviate on a strict gluten free diet. In refractory coeliac disease type I, the mucosal intraepithelial cell population is normal, whereas in type II a monoclonal cell population is atypical, which clearly increases the risk of enteropathy-associated T-cell lymphoma. ${ }^{66}$ Refractory coeliac disease should be managed in special clinics. $^{67}$

To conclude, increased risk of lymphoma clusters mainly in elderly coeliac patients. However, the risk is lower than previously thought, less than twofold in one recent series compared to that of the population in general. ${ }^{68}$ However, the malignant development should be rigorously investigated in refractory coeliac disease, and in cases where the patient experiences alarming symptoms or glutenfree diet is no longer effective.

Recently, llus et al ${ }^{68}$ reported that patients with coeliac disease carry an increased risk of colon cancer. This has to be borne in mind in elderly coeliac patients, because this cancer is very common, and its overall incidence is increasing in the older age groups. In those with coeliac disease who present with or develop iron deficiency anaemia, especially in later life, the possibility of concurrent colon cancer should always be considered. If iron deficiency anaemia is not reversed by a gluten free diet and supplements, the presence of a colon cancer should be suspected. 
In the same study, ${ }^{68}$ the risk of breast cancer in females and lung cancer were lower than in the population in general; these reductions may explain why the overall risk of cancer was not increased. ${ }^{68}$ A similar finding has also been observed non-significantly in smaller series $^{7}$

\subsection{How children differ in terms of symptoms}

In children, failure to thrive, anaemia and tiredness are typical symptoms. Lymphoma and is uncommon, but not absent, ${ }^{69}$ other malignancies occurring in children have not been connected to coeliac disease. As stated earlier, dermatitis herpetiformis is uncommon. Also in children, many remain undetected and have subtle if no symptoms at all. $^{70}$

\section{8 $\quad$ The effect of gluten-free diet}

Adopting a gluten free diet demands considerable changes in life style. Should the diagnosis of coeliac disease be pursued in the elderly, especially when symptoms are only mild? Several methods have been applied to measure quality of life in coeliac disease, these methods being mainly general and not disease-specific. Studies focusing on elderly coeliac patients are sparse.

The amelioration of the condition by gluten free diet is obvious when elderly coeliac patients suffer from classic symptoms or malabsorption. The issue becomes more complicated when there are only subtle, if any, symptoms or signs of malabsorption. Vilppula et al showed that the diet improves quality of life even in elderly screen detected coeliac disease patients, also in seemingly asymptomatic ones. ${ }^{5}$ This was particularly evident when quality of life was evaluated: in a series of 35 screen detected coeliac patients over 50 years of, 28 (77\%) maintained a strict gluten free diet while five others ingested gluten less than once per month. ${ }^{5}$ Compliance seems not to be a major problem as the majority of elderly coeliac patients, even apparently asymptomatic ones, adhere to a strict gluten free diet, which again improved their quality of life. Mucosal recovery is also expected to be good when the diet is strict, ${ }^{5}$ although it may occur more slowly than in younger patients. ${ }^{71}$ Hankey and Holmes found that compliance with gluten free diet in the elderly was good: in a study of 42 patients diagnosed at the age of 60 years or more, 38 (90\%) complied strictly with the diet. ${ }^{3}$ All of these reported a considerable improvement in well-being and resolution of symptoms after commencing diet. Weight increased by an average of $5.2 \mathrm{~kg}$; blood haemoglobin, albumin, calcium and alkaline phosphatase levels all improved significantly to within the normal range after 1 year on diet.

In the elderly, visual impairment that might impede the reading of food labels and the reliance on a partner to help with the gluten free diet. Where possible, partners should be involved in dietary and management discussions. Elderly patients, especially those who live alone might easily feel daunted by the thought of changing dietary habits of a life-time and fearful of the cost implications and how products might be obtained. For all of these reasons, patients should be introduced to sympathetic dieticians skilled in the gluten free diet, so that optimal management can be achieved. ${ }^{72}$ The risk of overweight is present after commencing gluten-free diet, and weight maintenance counselling should be an integral part of coeliac dietary education. ${ }^{73}$ Altogether, current limited evidence suggests adherence to a gluten-free diet and mucosal healing prevents or ameliorates complications. ${ }^{73}$

Before the diagnosis is pursued it should be established that patients are taking a full normal diet, because some will begin eliminating gluten as soon as the diagnosis of coeliac disease is mentioned, sometimes on the advice of their physicians. This should be strongly discouraged as it can make subsequent tests difficult to interpret.

\section{5 | DIAGNOSTIC WORK-UP OF COELIAC DISEASE IN ELDERLY PATIENTS}

Population-based screening for coeliac disease is not supported by the current evidence. ${ }^{74}$ The level of suspicion of coeliac disease should be as high in older people as in younger ones. Old age itself should never be blamed for clinical features such as tiredness, indigestion, reduced appetite or anaemia which may be due to coeliac disease. Individuals found to have coeliac disease through screening programmes, may have considered themselves as 'well' and it is the physician or healthcare system that is identifying them as potentially ill. A strategy of case-finding from groups at particular risk is preferable. $^{36}$ Individuals with a family history of coeliac disease have about a five-fold risk of having coeliac disease. ${ }^{75}$ An active case finding strategy increases the detection of coeliac disease, ${ }^{76}$ so health care workers should test patients with suggestive clinical features or because the belong to an at-risk group, for example, have a family history or autoimmune diseases, and where necessary, perform small intestinal biopsy to confirm or refute the diagnosis. Testing for coeliac disease in patients with suspected irritable bowel syndrome is likely to be cost-effective even at a relatively low coeliac disease prevalence. $^{25}$

In the series of 40 patients found by serologic screening in the studies of Vilppula et $\mathrm{al}^{16,17}$ diagnostic clues were present in almost every patient's history, and should alert physicians to consider coeliac disease. Patients with clinical features indicative of coeliac disease may be seronegative, and in these cases obtaining a small bowel biopsy is mandatory to clarify the situation. Especially elderly coeliac patients may remain seronegative, ${ }^{77}$ or tissue transglutaminase antibodies titres may be lower than in younger ones. ${ }^{70}$ In such symptomatic individuals endoscopic examination will also establish whether other pathology is present in the upper gastrointestinal tract. In frail, elderly patients or those with co-morbidities that preclude performing an endoscopy to obtain small bowel biopsies, serological tests will usually help to establish the diagnosis ${ }^{78,79}$

There is a role for establishing the HLA-status of patients which can rule out coeliac disease, as virtually all coeliac patients have DQ2 or DQ8. However, this is not helpful in the diagnostics of 
coeliac disease, because up to $35 \%$ of the population share DQ2 or DQ8. ${ }^{80}$

\section{6 | CONCLUSIONS}

Coeliac disease is often undetected in elderly people. The lack of obvious symptoms does not exclude the possibility of the condition. High index of suspicion and active serological screening in at-risk groups help to identify elderly patients who evidently benefit from gluten free diet. The diagnosis may prevent severe complications such as low-energy bone fractures and enteropathy-associated T-cell lymphoma.

\section{ACKNOWLEDGEMENTS}

Declaration of personal interests: None.

Declaration of funding interests: PC has investigated refractory coeliac disease for Celimmune. This manuscript was financially supported by the Competitive State Research Funding of the Expert Responsibility area of Tampere University Hospital (PC, KK), and by the Academy of Finland and The Sigfrid Juselius Foundation (KK).

\section{AUTHORSHIP}

Guarantor of the article: PC.

Author contributions: PC planned the first draft of the manuscript. All authors contributed to study design and writing of the manuscript. All authors approved the final version of the manuscript.

\section{ORCID}

\section{P. Collin iD http://orcid.org/0000-0002-4872-0416}

\section{REFERENCES}

1. Lohi S, Mustalahti K, Kaukinen $\mathrm{K}$, et al. Increasing prevalence of coeliac disease over time. Aliment Pharmacol Ther. 2007;26:1217-1225.

2. West J, Logan RF, Hill PG, et al. Seroprevalence, correlates, and characteristics of undetected coeliac disease in England. Gut. 2003;52:960-965.

3. Hankey GL, Holmes GKT. Coeliac disease in the elderly. Gut 1994:35:65-67.

4. Lewis NR, Holmes GKT. Risk of morbidity in contemporary celiac disease. Expert Rev Gastroenterol Hepatol. 2010;4:767-780.

5. Vilppula A, Kaukinen K, Luostarinen L, et al. Clinical benefit of gluten-free diet in screen-detected older celiac disease patients. BMC Gastroenterol. 2011;11:136.

6. Corrao G, Corazza GR, Bagnardi V, et al. Mortality in patients with coeliac disease and their relatives: a cohort study. Lancet. 2001;358:356-361.

7. Viljamaa M, Kaukinen K, Pukkala E, Hervonen K, Reunala T, Collin P. Malignancies and mortality in patients with coeliac disease and dermatitis herpetiformis: 30-year population-based study. Dig Liver Dis. 2006;38:374-380.
8. Dieterich W, Laag E, Schopper $\mathrm{H}$, et al. Autoantibodies to tissue transglutaminase as predictors of celiac disease. Gastroenterology. 1998;115:1317-1321.

9. Kaukinen K, Collin P, Laurila K, Kaartinen T, Partanen J, Maki M Resurrection of gliadin antibodies in coeliac disease. Deamidated gliadin peptide antibody test provides additional diagnostic benefit. Scand J Gastroenterol. 2007;42:1428-1433.

10. Sulkanen S, Collin P, Laurila K, Mäki M. IgA- and IgG-class antihuman umbilical cord antibody tests in adult coeliac disease. Scand $J$ Gastroenterol. 1998;33:251-254.

11. Casella S, Zanini B, Lanzarotto F, Villanacci V, Ricci C, Lanzini A Celiac disease in elderly adults: clinical, serological, and histological characteristics and the effect of a gluten-free diet. J Am Geriatr Soc. 2012;60:1064-1069.

12. Gasbarrini G, Ciccocioppo R, De Vitis I, Corazza GR. Coeliac disease in the elderly. A multicentre Italian study. Gerontology. 2001;47:306310.

13. Tortora R, Zingone F, Rispo A, et al. Coeliac disease in the elderly in a tertiary centre. Scand J Gastroenterol. 2016;51:1179-1183.

14. Holmes GKT, Muirhead A. Epidemiology of coeliac disease in a single centre in Southerrn Derbyside 1958-2014. BMJ Open Gastroenterology. 2017;4:e000137.

15. Singh P, Shergill S, Makharia GK. Celiac disease in older adults. J Gastrointest Liver Dis. 2013;22:59-60.

16. Vilppula A, Kaukinen $K$, Luostarinen L, et al. Increasing prevalence and high incidence of celiac disease in elderly people: a populationbased study. BMC Gastroenterol. 2009;9:49.

17. Vilppula A, Collin P, Maki M, et al. Undetected coeliac disease in the elderly: a biopsy-proven population-based study. Dig Liver Dis. 2008;40:809-813.

18. Virta L, Kaukinen K, Collin P. Incidence and prevalence of diagnosed coeliac disease in Finland: results of effective case finding in adults. Scand J Gastroenterol. 2009:44:933-938.

19. Kurppa K, Collin P, Viljamaa M, et al. Diagnosing mild enteropathy celiac disease: a randomized, controlled clinical study. Gastroenterology. 2009;136:816-823.

20. West J, Fleming KM, Tata LJ, Card TR, Crooks CJ. Incidence and prevalence of celiac disease and dermatitis herpetiformis in the UK over two decades: population-based study. Am J Gastroenterol. 2014;109:757-768.

21. Lockshin MD. Sex differences in autoimmune disease. Lupus. 2006;15:753-756.

22. Ciacci C, Cirillo M, Sollazzo R, Savino G, Sabbatini F, Mazzacca G. Gender and clinical presentation in adult celiac disease. Scand J Gastroenterol. 1995;30:1077-1081.

23. Bai D, Brar P, Holleran S, Ramakrishnan R, Green PH. Effect of gender on the manifestations of celiac disease: evidence for greater malabsorption in men. Scand J Gastroenterol. 2005;40:183187.

24. Markle JG, Frank DN, Mortin-Toth S, et al. Sex differences in the gut microbiome drive hormone-dependent regulation of autoimmunity. Science. 2013;339:1084-1088.

25. Mein SM, Ladabaum U. Serological testing for coeliac disease in patients with symptoms of irritable bowel syndrome: a cost-effectiveness analysis. Aliment Pharmacol Ther. 2004;19:1199-1210.

26. Mukherjee R, Egbuna I, Brar P, et al. Celiac disease: similar presentations in the elderly and young adults. Dig Dis Sci. 2010;55:31473153.

27. Vivas S, Vaquero L, Rodriguez-Martin L, Caminero A. Age-related differences in celiac disease: specific characteristics of adult presentation. World J Gastrointest Pharmacol Ther. 2015;6:207-212.

28. Collin P, Salmi TT, Hervonen K, Kaukinen K, Reunala T. Dermatitis herpetiformis: a cutaneous manifestation of coeliac disease. Ann Med. 2017;49:23-31. 
29. Salmi TT, Hervonen K, Kautiainen H, Collin P, Reunala T. Prevalence and incidence of dermatitis herpetiformis: a 40-year prospective study from Finland. Br J Dermatol. 2011;165:354-359.

30. Collin P, Huhtala H, Virta L, Kekkonen L, Reunala T. Diagnosis of celiac disease in clinical practice: physician's alertness to the condition essential. J Clin Gastroenterol. 2007;41:152-156.

31. Hervonen K, Vornanen M, Kautiainen H, Collin P, Reunala T. Lymphoma in patients with dermatitis herpetiformis and their firstdegree relatives. Br J Dermatol. 2005;152:82-86.

32. Hervonen K, Alakoski A, Salmi TT, et al. Reduced mortality in dermatitis herpetiformis: a population-based study of 476 patients. $\mathrm{Br}$ Dermatol. 2012;167:1331-1337.

33. Swerdlow AJ, Whittaker S, Carpenter LM, English JSC. Mortality and cancer incidence in patients with dermatitis herpetiformis: a cohort study. Br J Dermatol. 1993;129:140-144.

34. Mustalahti K, Collin P, Sievanen H, Salmi J, Maki M. Osteopenia in patients with clinically silent coeliac disease warrants screening. Lancet. 1999;354:744-745.

35. Cellier C, Flobert C, Cormier C, Roux C, Schmitz J. Severe osteopenia in symptom-free adults with a childhood diagnosis of coeliac disease. Lancet. 2000;355:806.

36. Lewis NR, Scott BB. Guidelines on osteoporosis in coeliac disease and inflammatory bowel disease. British Society of Gastroenterology; 2007. http://www.bsg.org.uk

37. Godfrey JD, Brantner TL, Brinjikji W, et al. Morbidity and mortality among older individuals with undiagnosed celiac disease. Gastroenterology. 2010;139:763-769.

38. West J, Logan RF, Card TR, Smith C, Hubbard R. Fracture risk in people with celiac disease: a population-based cohort study. Gastroenterology. 2003;125:429-436.

39. Olmos M, Antelo M, Vazquez H, Smecuol E, Maurino E, Bai JC. Systematic review and meta-analysis of observational studies on the prevalence of fractures in coeliac disease. Dig Liver Dis. 2008;40:4653.

40. Espallargues M, Sampietro-Colom L, Estrada MD, et al. Identifying bone-mass-related risk factors for fracture to guide bone densitometry measurements: a systematic review of the literature. Osteoporos Int. 2001;12:811-822.

41. Tortora R, Imperatore N, Capone P, et al. FRAX Score can be used to avoid superfluous DXA scans in detecting osteoporosis in celiac disease: accuracy of the FRAX score in celiac patients. J Clin Densitom. 2017;. https://doi.org/10.1016/j.jocd.2017.05.010

42. Kanis JA, Johnell O, Oden A, Dawson A, De Laet C, Jonsson B. Ten year probabilities of osteoporotic fractures according to BMD and diagnostic thresholds. Osteoporos Int. 2001;12:989-995.

43. Stenson WF, Newberry R, Lorenz R, Baldus C, Civitelli R. Increased prevalence of celiac disease and need for routine screening among patients with osteoporosis. Arch Intern Med. 2005;165:393-399.

44. Iltanen S, Collin P, Korpela M, et al. Celiac disease and markes of celiac disease latency in patients with primary Sjögren's syndrome. Am J Gastroenterol. 1999;94:1042-1046.

45. Freeman HJ. Celiac-associated autoimmune thyroid disease: a study of 16 patients with overt hypothyroidism. Can J Gastroenterol. 1995;9:242-246.

46. Meloni A, Mandas C, Jores RD, Conmgia M. Prevalence of autimmune thyroid diseases in with $C D$ and effect of gluten withdrawal. $J$ Pediatr. 2009;155:51-55.

47. Collin P, Kaukinen K, Välimäki M, Salmi J. Endocrinological disorders and celiac disease. Endocr Rev. 2002;23:464-483.

48. Sategna-Guidetti C, Volta U, Ciacci C, et al. Prevalence of thyroid disorders in untreated adult celiac disease patients and effect of gluten withdrawal: an Italian multicenter study. Am J Gastroenterol. 2001;96:751-757.
49. Ludvigsson J, James S, Askling J, Stenestrand U, Ingelsson E. Natiowide cohort study of risk of ischmecc heart disease in patients with CD. Circulation. 2011;123:4873-4890.

50. Emilsson L, Carlsson R, Holmqvist M, James S, Ludvigsson JF. The characterisation and risk factors of ischaemic heart disease in patients with coeliac disease. Aliment Pharmacol Ther. 2013;37:905914.

51. Lebwohl B, Cao Y, Zong G, et al. Long term gluten consumption in adults without celiac disease and risk of coronary heart disease: prospective cohort study. BMJ. 2017;357:j1892.

52. Hadjivassiliou M, Gibson A, Davies-Jones GAB, Lobo AJ, Stephenson TJ, Milford-Wars A. Does cryptic gluten sensitivity play a part in neurological illness? Lancet. 1996;347:369-371.

53. Hadjivassiliou M, Grunewald RA, Chattopadhyay AK, et al. Clinical, radiological, neuropscyhological, and neuropathological characteristics of gluten ataxia. Lancet. 1998;352:1582-1585.

54. Hadjivassiliou M, Sanders DS, Grunewald RA, Woodroofe N, Boscolo S, Aeschlimann D. Gluten sensitivity: from gut to brain. Lancet Neurol. 2010;9:318-330.

55. Lebwohl B, Luchinger JA, Freedberg DE, Green PHR. Risk of dementia in patients with celiac disease: a population-based cohort study. J Alzheimer's Dis. 2016;49:179-185.

56. Luostarinen L, Pirttila T, Collin P. Coeliac disease presenting with neurological disorders. Eur Neurol. 1999;42:132-135.

57. Luostarinen LK, Collin PO, Peraaho MJ, Maki MJ, Pirttila TA. Coeliac disease in patients with cerebellar ataxia of unknown origin. Ann Med. 2001;33:445-449.

58. Tio M, Cox MR, Eslick GD. Meta-analysis: coeliac disease and the risk of all-cause mortality, any malignancy and lymphoid malignancy. Aliment Pharmacol Ther. 2012;35:540-551.

59. Catassi C, Bearzi I, Holmes GK. Association of celiac disease and intestinal lymphomas and other cancers. Gastroenterology. 2005;128: S79-S86.

60. Holmes GKT, Prior P, Lane MR, Pope D, Allan RN. Malignancy in coeliac disease - effect of a gluten free diet. Gut. 1989;30:333-338.

61. Ludvigsson JF. Mortality and malignancy in celiac disease. Gastrointest Endosc Clin N Am. 2012;22:705-722.

62. Freeman HJ. Adult celiac disease and its malignant complications. Gut Liv. 2009;3:237-246.

63. Collin P, Pukkala E, Reunala T. Malignancy and survival in dermatitis herpetiformis: a comparison with coeliac disease. Gut. 1996;38:528530.

64. Cellier C, Delabesse E, Helmer C, et al. Refractory sprue, coeliac disease, and enteropathy-associated T-cell lymphoma. Lancet. 2000;356:203-208.

65. Ilus T, Kaukinen K, Virta LJ, et al. Refractory coeliac disease in a country with a high prevalence of clinically-diagnosed coeliac disease. Aliment Pharmacol Ther. 2014;39:418-425.

66. Mulder CJ, Wahab PJ, Moshaver B, Meijer JW. Refractory coeliac disease: a window between coeliac disease and enteropathy associated T cell lymphoma. Scand J Gastroenterol Suppl. 2000;232:32-37.

67. Rubio-Tapia A, Malamut G, Verbeek WH, et al. Creation of a model to predict survival in patients with refractory coeliac disease using a multinational registry. Aliment Pharmacol Ther. 2016;44:704-714.

68. Ilus T, Kaukinen K, Virta LJ, Pukkala E, Collin P. Incidence of malignancies in diagnosed celiac patients: a population-based estimate. Am J Gastroenterol. 2014;109:1471-1477.

69. Chisini M, Bacci F, de Propris MS, et al. Enteropathy-associated Tcell lymphoma in childhood: a case report and review of the literature. Leuk Lymphoma. 2015;56:2743-2746.

70. Vivas S, Ruiz de Morales JM, Fernandez M, et al. Age-related clinical, serological, and histopathological features of celiac disease. Am J Gastroenterol. 2008;103:2360-2365. 
71. Mahadev S, Murray JA, Wu TT, et al. Factors associated with villus atrophy in symptomatic coeliac disease patients on a gluten-free diet. Aliment Pharmacol Ther. 2017;45:1084-1093.

72. Villafuerte-Galvez J, Vanga RR, Dennis $M$, et al. Factors governing long-term adherence to a gluten-free diet in adult patients with coeliac disease. Aliment Pharmacol Ther. 2015;42:753-760.

73. Haines ML, Anderson RP, Gibson PR. Systematic review: the evidence base for long-term management of coeliac disease. Aliment Pharmacol Ther. 2008;28:1042-1066.

74. Chou R, Bougatsos C, Blazina I, Mackey K, Grusing S, Selph S. Screening for celiac disease: evidence report and systematic review for the US preventive services task force. JAMA. 2017;317:1258-1268.

75. Singh P, Arora S, Lal S, Strand TA, Makharia GK. Risk of celiac disease in the first- and second-degree relatives of patients with celiac disease: a systematic review and meta-analysis. Am J Gastroenterol. 2015;110:1539-1548.

76. Catassi C, Kryszak D, Louis-Jacques O, et al. Detection of celiac disease in primary care: a multicenter case-finding study in North America. Am J Gastroenterol. 2007;102:1454-1460.

77. Salmi TT, Collin P, Korponay-Szabo IR, et al. Endomysial antibodynegative coeliac disease: clinical characteristics and intestinal autoantibody deposits. Gut. 2006;55:1746-1753.

78. Hill PG, Holmes GK. Coeliac disease: a biopsy is not always necessary for diagnosis. Aliment Pharmacol Ther. 2008;27:572-577.

79. Holmes GKT, Forsyth JM, Knowles S, Seddon H, Hill PG, Austin AS. Coeliac disease: further evidence that biopsy is not always necessary for diagnosis. Eur J Gastroenterol Hepatol. 2017;29:640-645.

80. Kaukinen K, Partanen J, Maki M, Collin P. HLA-DQ typing in the diagnosis of celiac disease. Am J Gastroenterol. 2002;97:695-699.

81. Kolho K-L, Färkkilä MA, Savilahti E. Undiagnosed coeliac disease is common in Finnish adults. Scand J Gastroenterol. 1998;33:1280-1283.

82. Ivarsson A, Persson LÅ, Juto P, Peltonen M, Suhr O, Hernell O. High prevalence of undiagnosed coeliac disease in adults: a Swedish population-based study. J Intern Med. 1999;245:63-68.
83. Volta U, Bellentani S, Bianchi F, et al. High prevalence of celiac disease in Italian general population. Dig Dis Sci. 2001;47:1500-1505.

84. Katz KD, Rashtak S, Lahr BD, et al. Screening for celiac disease in a North American population: sequential serology and gastrointestinal symptoms. Am J Gastroenterol. 2011;106:1333-1339.

85. Almeida LM, Castro LC, Uenishi RH, et al. Decreased prevalence of celiac disease among Brazilian elderly. World J Gastroenterol. 2013;19:1930-1935.

86. Murray JA, Van Dyke C, Plevak MF, Dierkhising RA, Zinsmeister AR, Melton $\mathrm{L}$ 3rd. Trends in the identification and clinical features of celiac disease in a North American community, 1950-2001. Clin Gastroenterol Hepatol. 2003;1:19-27.

87. Fowell A, Thomas P, Surgenor S, Snook J. The epidemiology of coeliac disease in East Dorset 1993-2002: an assessment of the 'coeliac iceberg', and preliminary evidence of case clustering. QJM. 2006;99:453-460.

88. Angeli G, Pasquini R, Panella V, Pelli MA. An epidemiologic survey of celiac disease in the Terni area (Umbria, Italy) in 2002-2010. J Prev Med Hyg. 2012;53:20-23.

89. Ludvigsson J, Rubio-Tapia A, van Dyke C, et al. Increasing incidence of celiac disease in a North American population. Am J Gastroenterol. 2013;108:818-824.

90. Freeman HJ. Clinical spectrum of biopsy-defined celiac disease in the elderly. Can J Gastroenterol. 1995;9:42-46.

How to cite this article: Collin P, Vilppula A, Luostarinen L, Holmes GKT, Kaukinen K. Review article: coeliac disease in later life must not be missed. Aliment Pharmacol Ther.

2018;47:563-572. https://doi.org/10.1111/apt.14490 